\title{
Serum hepcidin and interleukin-6 in systemic lupus erythematosus patients: crucial factors for correction of anemia
}

\author{
Abeer M. El-Shafey ${ }^{1 *}$, Lamiaa M. Kamel ${ }^{2}$, Abeer A. Fikry², Mohamad M. Nasr ${ }^{3}$ and Sahar M. Abdel Galil ${ }^{1,4}$
}

\begin{abstract}
Background: The incidence rate of anemia of chronic disease (ACD) in systemic lupus erythematosus (SLE) ranges between 30 and $80 \%$. Serum iron is the main regulator of hepatic hepcidin production. Interleukin-6 (IL-6) upregulates hepcidin expression. The aim of this study is to compare between serum hepcidin and IL-6 in SLE patients and control subjects, and to find out if they are correlated with each other and with disease activity in order to find their role in treatment of anemia in SLE patients.

The study was carried out on 50 SLE patients, suffering from anemia, diagnosed according to SLICC revision of the ACR classification criteria for SLE, and 50 healthy individuals, taken as control. Disease activity was assessed using the SLE disease activity index (SLEDAI-2 K). Serum hepcidin and IL-6 were measured by ELISA kit.

Results: There was a highly statistically significant difference in serum hepcidin and IL-6 levels between patients and control subjects. There was a statistically significant correlation between serum hepcidin and IL-6 in SLE patients. Moreover, both of them were correlated with SLEDAI and ESR and negatively correlated with hemoglobin. The mean value of serum hepcidin in SLE patients with normocytic normochromic anemia was higher than that in patients with microcytic hypochromic anemia. However, this difference did not reach a statistically significant level.

Conclusion: High serum IL-6 and hepcidin levels are associated with anemia in SLE. They are correlated with each other and with disease activity. Although our study revealed serum hepcidin to be correlated with disease activity, it should not be used as a marker of disease activity in SLE patients as our patient's group was SLE patients suffering from ACD. However, IL-6 inhibition should be considered in patients with SLE with anemia to guide the control of anemia of chronic diseases resulting from cytokine production as a result of high disease activity in SLE patients. It should be noted that the occurrence of ACD associated with IL-6 flare up could be a player in other systemic rheumatic diseases and is not specific to SLE patients.
\end{abstract}

Keywords: Systemic lupus erythematosus, Hepcidin, IL-6, Anemia of chronic disease, Iron-deficiency anemia, Normochromic normocytic anemias

\section{Background}

Systemic lupus erythematosus is a systemic autoimmune disease that is characterized by multisystem involvement. Clinical features in SLE patients vary between mild joint and skin involvement to severe, life-threatening internal

\footnotetext{
* Correspondence: abeerelshafey@hotmail.com

'Rheumatology and Rehabilitation Department, Faculty of Medicine, Zagazig University, Al-Modeer street, Zagazig 44519, Egypt

Full list of author information is available at the end of the article
}

organ disease. Anemia of chronic disease (ACD) is the commonest anemia in SLE [1], with an incidence rate $30-80 \%[2]$.

Hepcidin regulates iron homeostasis. It prevents mobilization of iron stored in macrophages and prevents absorption of iron from the gut [3]. It contributes to anemia by limiting iron availability for erythropoiesis. Hepcidin is, mainly, produced by the liver, but it is made elsewhere, including the kidney and macrophages [4].

\section{Springer Open}

(๑) The Author(s). 2020 Open Access This article is licensed under a Creative Commons Attribution 4.0 International License, which permits use, sharing, adaptation, distribution and reproduction in any medium or format, as long as you give appropriate credit to the original author(s) and the source, provide a link to the Creative Commons licence, and indicate if changes were made. The images or other third party material in this article are included in the article's Creative Commons licence, unless indicated otherwise in a credit line to the material. If material is not included in the article's Creative Commons licence and your intended use is not permitted by statutory regulation or exceeds the permitted use, you will need to obtain permission directly from the copyright holder. To view a copy of this licence, visit http://creativecommons.org/licenses/by/4.0/. 
Hepcidin regulates iron absorption and iron cycling in the hepatic stores [5]. Serum iron is the main regulator of hepatic hepcidin production. Interleukin-6 (IL-6) upregulates hepcidin expression, which may explain the ACD [6].

It has been stated that hepcidin increased 100 times during inflammation. It decreases iron absorption in the bowels, holds iron in macrophages, and decreases plasma iron level [7].

Infusion of IL-6 to healthy individuals increased hepcidin level, increased serum iron levels, and decreased transferrin saturation [8].

The aim of this study is to assess serum hepcidin and IL-6 in anemic SLE patients, and to find out if they are correlated with each other and with disease activity, in order to find out their role in treatment of anemia in SLE patients.

\section{Methods}

\section{Study population}

This is a case control study, which was carried out on 50 Egyptian SLE patients, suffering from anemia, and 50 healthy individuals, age and sex matched with patients, taken as control.

SLE patients were diagnosed according to SLICC revision of the ACR classification criteria for SLE [9]. Healthy individuals were selected if they have no history of any disease, with normal hemoglobin level, ESR, CRP, LFTs, and KFTs.

Patients were recruited from the inpatient sections and outpatient clinics of rheumatology and rehabilitation department, during the period of January 2018 to July 2018.

Informed consent was obtained from all individual participants included in the study. The study was approved by the Institutional Review Board (IRB) of the faculty.

Patients were subjected to full history taking and general examination for the presenting clinical manifestations. Disease activity was assessed using the SLE disease activity index (SLEDAI-2 K) [10].

Patients were considered anemic if their $\mathrm{Hb}$ was $<12$ $\mathrm{g} / \mathrm{dl}$ in females or $<15 \mathrm{~g} / \mathrm{dl}$ in males, according to WHO threshold used to define anemia [11]. Anemia was defined as microcytic if mean corpuscular volume (MCV) is below $83 \mathrm{fl}$ and was defined as hypochromic if mean corpuscular hemoglobin $(\mathrm{MCH})$ was below $27 \mathrm{pg}$ [12].

Patients with hemolytic anemia associated antiphospholipid antibody syndrome (APS) and patients with established nephropathy were excluded from the study.

\section{Laboratory investigations}

Routine laboratory investigations were performed for diagnosis and follow-up of SLE patients, such as ESR,
CRP, liver and kidney function tests, $24 \mathrm{~h}$ urinary proteins, C3, and C4 levels. Anti-double stranded DNA (anti-ds-DNA) antibodies were detected and specified using immunofluorescence technique.

Five milliliters of blood were collected, from all the study participants, about $2 \mathrm{ml}$ on EDTA tube for CBC and $3 \mathrm{ml}$ on plain tube which was left for $30 \mathrm{~min}$ then centrifuge to separate serum with immediate measurement of serum iron, then part of serum was stored at 20 for further analysis of serum hepcidin by ELISA kit supplied by Elabscience and IL- 6 by ELISA kit supplied by affymetrix eBioscience.

\section{Statistical analysis}

All statistical analyses were performed with SPSS, version 21.0 (IBM Corp, NY, USA). Quantitative data were presented by mean and standard deviation (SD). $t$ test was used for comparison between two groups. Spearman's correlation $(r)$ was done to show the closeness of association between two variables. Results were considered significant if $P$ value is $<0.05$ and highly significant if $P$ value is $<0.001$.

\section{Results}

\section{Patient characteristics}

This study was carried out on 50 SLE patients and 50 healthy control subjects. SLE patients were 45 females (90\%) and 5 males (10\%). Their ages ranged from 25 to 37 years old, with a mean of $30.7 \pm 3.3$. Their disease duration ranged from 1 to 7 years, with a mean of $4+$ 1.45 years. The control subjects were 43 females (86\%) and 7 males (14\%). Their ages ranged from 20 to 40 years old, with a mean of $29.9 \pm 5.3$. There was no statistically significant difference between patients and control as regard age or sex ( $P$ value 0.17 and 0.24 , respectively).

\section{Serum hepcidin and IL-6 levels}

There was a highly statistically significant difference in serum hepcidin levels between patients and control subjects. The mean value of serum hepcidin in SLE patients was $(78.7 \mathrm{ng} / \mathrm{ml})$ more than double that of the mean value in the control group $(35.5 \mathrm{ng} / \mathrm{ml})$ (Table 1$)$.

There was, also, a highly statistically significant difference in serum IL-6 levels between patients and control subjects. The mean value of serum IL- 6 in SLE patients was 6 folds higher than that in the control group (Table 1).

\section{Correlation with disease activity and $\mathrm{Hb}$ level}

There was a statistically significant correlation between serum hepcidin and IL-6 in SLE patients. Moreover, both of them were correlated with SLEDAI and ESR. Besides, serum hepcidin showed statistically significant negative correlation with $\mathrm{Hb}$ level and IL-6 showed 
Table 1 Serum hepcidin and IL-6 in SLE patients and control

\begin{tabular}{|c|c|c|c|c|}
\hline & SLE patients, $N(50)$ & Control, N (50) & $t$ & $P$ \\
\hline \multicolumn{5}{|l|}{ Age (years) } \\
\hline Mean \pm SD & $30.7 \pm 3.3$ & $29.9 \pm 5.3$ & & 0.17 \\
\hline Sex & $N(\%)$ & $N(\%)$ & & \\
\hline Male & $5(10 \%)$ & $7(14 \%)$ & & 0.24 ethics \\
\hline Female & 45 (90\%) & $43(86 \%)$ & & \\
\hline \multicolumn{5}{|c|}{ Hepcidin (ng/ml) } \\
\hline Mean \pm SD & $78.7 \pm 13.6$ & $35.5 \pm 5.5$ & 16.5 & $<0.001^{* *}$ \\
\hline \multicolumn{5}{|l|}{ IL-6 (pg/ml) } \\
\hline Mean + SD & $12.9+4.2$ & $2.6+0.8$ & 7.49 & $<0.001^{* *}$ \\
\hline
\end{tabular}

$S D$ standard deviation

** Significance at $P$ value $<0.001$

highly statistically significant negative correlation with Hb level (Table 2).

\section{Hepcidin and IL- 6 levels in different grades and different types of anemia}

Our results showed that, the mean level of serum hepcidin in SLE patients with normocytic normochromic anemia was higher than that in patients with microcytic hypochromic anemia. However, this difference did not reach a statistically significant level (Table 3 ).

\section{Discussion}

Systemic lupus erythematosus is a potentially severe autoimmune disease with characteristic production of inflammatory cytokines and autoreactive antibodies due to the lack of immune tolerance leading to diverse clinical manifestations and damage to various organs, including skin, joints, kidneys, and the central nervous system [13]. SLE course is variable, mainly characterized by remission and relapse periods [14].

Hematologic involvement is common in SLE; all three blood cell lines could be affected. ACD is a normochromic, normocytic anemia, in which there is low serum iron, low transferrin, and normal or increased serum ferritin. It can coexist with anemia resulting from other

Table 2 Correlations of serum hepcidin and IL-6 with each other, and with hemoglobin level and markers of inflammation in SLE patients

\begin{tabular}{llllll}
\hline & \multicolumn{2}{l}{ Hepcidin } & & \multicolumn{1}{l}{ L-6 } & \\
\cline { 2 - 3 } \cline { 5 - 6 } & $r$ & & & $r$ & $P$ \\
\hline SLEDAI & 0.32 & $<0.05^{*}$ & & 0.21 & $0.046^{*}$ \\
ESR & 0.48 & $<0.05^{*}$ & & 0.33 & $0.040^{*}$ \\
$\mathrm{Hb}$ & -0.55 & $0.04^{*}$ & & -0.67 & $0.001^{*}$ \\
IL-6 & 0.48 & $0.002^{*}$ & & - & - \\
Hepcidin & - & - & & 0.48 & $0.002^{*}$ \\
\hline
\end{tabular}

*Significance at $P$ value $<0.05$ processes [1]. The incidence rate of ACD in SLE ranges between 30 and $80 \%$ [2].

It has been stated that ACD is characterized by iron retention inside the macrophage, induced by cytokines and hepcidin, which controls cellular iron efflux by binding to the iron export protein, ferroportin [15].

This study was designed to assess serum hepcidin and IL-6 levels in SLE patients suffering from anemia, and to study their correlation with each other and with SLEDAI.

In our study, both serum hepcidin and IL-6 levels were statistically higher in SLE patients when compared to control subjects (Table 1).

High serum hepcidin and IL-6 were correlated with each other and with SLEDAI and ESR (Table 2).

High serum hepcidin levels showed a statistically significant negative correlation with $\mathrm{Hb}$ level and IL-6 showed a highly statistically significant negative correlation with $\mathrm{Hb}$ level (Table 2). These results confirm that high levels of serum hepcidin and IL-6 are contributing to the severity of anemia.

Surprisingly, in this work, the mean level of serum hepcidin in SLE patients with normocytic normochromic anemia was higher than that in patients with microcytic hypochromic anemia. However, this difference did not reach a statistically significant level (Table 3). This finding pays the attention to elevated hepcidin level as a causative factor for ACD as well as IDA.

Previous studies had reported significant increase in serum hepcidin in SLE patients, when compared with control subjects [16]. Other numerous studies had stated that IL-6 in SLE patients was significantly higher than in control subjects [17-21].

It has been stated that urinary hepcidin is increased in anemic SLE patients, when compared with the control group [22]. Moreover, serum hepcidin was significantly higher in SLE patients with anemia than in patients with only IDA [16].

Shao et al. [19] and Chen et al. [23] found significant correlation between IL-6 and SLEDAI in their separate studies. Moreover, urinary IL-6 was correlated with SLEDAI and was reported as a useful parameter to assess disease activity in SLE patients [24].

It has been reported that hepcidin plays a role in ACD in autoimmune disease, and it was correlated with disease activity [25].

Mok et al. reported that serum hepcidin and IL-6 are correlated with disease activity in SLE patients, and are associated with ACD [26].

Demirag and colleagues found that hepcidin was negatively correlated with $\mathrm{Hb}$ in ACD [25]. Another study reported that treatment with IL-6 antagonists in RA has resulted in fall of hepcidin levels and increase in hemoglobin levels [27]. 
Table 3 Serum hepcidin in normocytic normochromic and microcytic hypochromic anemia in SLE patients

\begin{tabular}{llll}
\hline & Normocytic normochromic & Microcytic hypochromic & $t$ \\
\hline Serum hepcidin $(\mathrm{ng} / \mathrm{ml})$ & & & $P$ \\
Mean \pm SD & $81.3 \pm 13.8$ & $71.5 \pm 14.8$ & 1.55 \\
Range & $65-100$ & $55-89$ & \\
\hline
\end{tabular}

$S D$ standard deviation

It has been stated that hepcidin determination may aid to differentiate between ACD and IDA and in selecting appropriate therapy for patients [15]. Oral treatment of IDA will be ineffective if hepcidin is blocking gut absorption. In this case, parenteral iron treatment would be more appropriate [28]. This finding makes hepcidin assessment essential prior to starting iron therapy.

Old reports had stated that prohepcidin was significantly higher in ACD [29].

The previous results may be explained by that IL-1 and IL-6, which are increasing in inflammation, stimulate hepcidin production by the liver [30, 31]. Hepcidin represses the ferroportin expression, leading to iron retention in the macrophages and preventing direct iron absorption in the circulation, leading to IDA [25].

Moreover, cytokines such as TNF- $\alpha$, IFN- $\alpha$, IL-1, and IL-6 promote dysfunctions in the differentiation and proliferation of erythroid precursors, leading to ACD [32]

Dagli et al. concluded that controlling the release of hepcidin, prohepcidin, and other cytokines contribute to the treatment of ACD [16].

Ganeb et al. concluded that prohepcidin may play a role in ACD occurring in autoimmune diseases, such as RA and SLE [33].

\section{Conclusion}

From our data and others', we conclude that hepcidin has a potential role in ACD, as well as IDA in SLE patients. Serum IL-6 and hepcidin levels are associated with anemia in these patients. In view of the finding that serum hepcidin is correlated with IL-6 as well as disease activity, IL-6 inhibitors should be considered in active SLE with anemia to control their disease activity, as well as correcting their anemia.

\section{Abbreviations}

ACD: Anemia of chronic disease; ACR: American College of Rheumatology; APS: Anti-phospholipid syndrome; IDA: Iron-deficiency anemia; INFa: Interferon alpha; IL-6: Interlukin-6; MCH: Mean corpuscular hemoglobin; MCV: Mean corpuscular volume; RA: Rheumatoid arthritis; SLE: Systemic lupus erythematosus; SLEDAl: Systemic lupus erythematosus disease activity index; TNF-a: Tumor necrosis factor alpha

\section{Authors' contributions}

All authors have read and approved the manuscript. AE had a major contribution in writing the manuscript, has formulated and revised the manuscript. MN has collected patients' data and participated in statistical analysis of patients' data. LK and AF have performed laboratory assessment of serum hepcidin and other laboratory investigations. SA performed clinical assessment of patients and has graded and assessed SLEDAI.

\section{Funding}

Not applicable.

\section{Availability of data and materials}

Not applicable.

\section{Ethics approval and consent to participate}

The study was approved by the Institutional Review Board (IRB) of Faculty of Medicine, Zagazig University (reference number ZU-IRB\#4570/20-11-2017).

Informed consents were obtained from each participant.

\section{Consent for publication}

Not applicable.

\section{Competing interests}

The authors declare that they have no competing interests.

\section{Author details}

${ }^{1}$ Rheumatology and Rehabilitation Department, Faculty of Medicine, Zagazig University, Al-Modeer street, Zagazig 44519, Egypt. ${ }^{2}$ Clinical Pathology Department, Faculty of Medicine, Zagazig University, Zagazig, Egypt. ${ }^{3}$ Dermatology \& Venereology Department, Faculty of Medicine, Zagazig University, Zagazig, Egypt. ${ }^{4}$ Medicine Department, Faculty of Medicine, Umm Al-Qura University, Makkah, Saudi Arabia.

Received: 31 March 2020 Accepted: 18 May 2020

Published online: 08 July 2020

\section{References}

1. Dall'Era M \& Wofsy D. Clinical features of systemic lupus erythematosus. In: Firestein GS, Budd RC, Gabriel SE, McInnes IB, O'Dell JR (ed) KELLEY \& FIRESTEIN'S Textbook of Rheumatology, $10^{\text {th }}$ edition, 2017. Philadelphia, pp 1354-1367 e3.

2. Ganz T (2005) Hepcidin-a regulator of intestinal iron absorption and iron recycling by macrophages. Best Pract Res Clin Hematol 18(2):171-182

3. Zhang X, Rovin BH (2013) Beyond anemia: hepcidin, monocytes and inflammation. Biol Chem 394:231-238

4. Theurl I, Theurl M, Seifert M, Mair S, Nairz M, Rumpold H et al (2008) Autocrine formation of hepcidin induces iron retention in human monocytes. Blood 111:2392-2399

5. Ganz T (2004) Hepcidin in iron metabolism. Curr Opin Hematol 11(4): $251-254$

6. Weiss G, Goodnough LT (2005) Anemia of chronic disease. N Engl J Med 352:1011-1023

7. Wilson A, Yu HT, Goodnough LT, Nissenson AR (2004) Prevalence and outcomes of anemia in rheumatoid arthritis: a systematic review of the literature. Am J Med 116(suppl 7A):S50-S57

8. Vreugdenhil G, Lowenberg B, Van Eijk HG, Swaak AJ (1992) Tumor necrosis factor alpha is associated with disease activity and the degree of anemia in patients with rheumatoid arthritis. Eur J Clin Invest 22:488-493

9. Petri M (2009) Systemic Lupus International Collaborating Clinic (SLICC): SLICC revision of the ACR classification for SLE. Arth Rheum 64(8):2677-2686 
10. Gladman DD, Iban ez D, Urowitz MB. Systemic lupus erythematosus disease activity index 2000. J Rheumatol 2002;29: 288-291.

11. World Health Organization. Worldwide prevalence of anemia 1993-2005. Geneva 2008: World Health Organization 2009.www.ewb.archive.org.

12. Bates \& Lewis. Reference ranges and normal values. In: Dacie and lewis Practical Haematology $11^{\text {th }}$ edition. Bain JB, Bates I, Laffan MA, Lewis SM.; ELSEVIER 2001, Philadelphia, chapter (2): 19-28.

13. Yazdanpanah E, Mahmoudi M, Sahebari M, Rezaieyazdi Z, Esmaeili SA, Tabasi N et al (2017) Vitamin D3 alters the expression of toll-like receptors in peripheral blood mononuclear cells of patients with systemic lupus erythematosus. J Cell Biochem 9999:1-5

14. Fernandez D and Kirou K. What causes lupus flares? Curr Rheumatol Rep 2016;18: 1-14

15. Theurl I, Aigner E, Theurl M, Nairz M, Seifert M, Schroll A et al (2009) Regulation of iron homeostasis in anemia of chronic disease and iron deficiency anemia: diagnostic and therapeutic implications. Blood 113(21): 5277-5286

16. Dagli M, Yilmaz S, Sivrikaya A, Cehk G, Vatansev H (2011) The role of prohepcidin and hepcidin in anemia associated with systemic lupus erythemayosus. World Applied Sciences Journal 13(9):2032-2036

17. Grondal G, Gunnarsson I, Ronnelid J, Rogberg S, Klareskog L, Lundberg I (2000) Cytokine production, serum levels and disease activity in systemic lupus erythematosus. Clin Exp Rheumatol 18:565-570

18. Chun H, Chung J, Kim H, Yun JM, Jeon JY, Ye YM et al (2007) Cytokine IL-6 and IL-10 as biomarkers in systemic lupus erythematosus. J Clin Immunol 27:461-466

19. Hu S, Xiao W, Kong F, Ke D, Qin R, Su M (2008) Regulatory T cells and their molecular markers in peripheral blood of the patients with systemic lupus erythematosus. J Huazhong Univ Sci Technolog Med Sci 28(5):549-552

20. Ripley B, Goncalves B, Isenberg D, Latchman DS, Rahman A (2005) Raised levels of interleukin 6 in systemic lupus erythematosus correlate with anaemia. Ann Rheum Dis 64:849-853

21. Yongkang W, Cai B, Zhang J, Shen B, Huang Z, Tan C et al (2017) IL-1 $\beta$ and IL-6 are highly expressed in RF + IgE+ systemic lupus erythematous subtype. Journal of Immunology Research:5096741. https://doi.org/10.1155/ 2017/5096741

22. Nemeth E, Valore EV, Terrilo M, Schiller G, Lichtenstein A, Ganz T (2003) Hepcidin, a putative mediator of anemia of inflammation, is a type II acute phase protein. Blood 101:2461-2463

23. Chen X, Yu Y, Deng H, Sun JZ, Dai Z, Wu YW et al (2010) Plasma IL-17A is increased in new-onset SLE patients and associated with disease activity. J Clin Immunol 30:221-225

24. Dima A, Jurcut C, Balanescu P, Balanescu E, Badea C, Caraiola S et al (2017) Clinical significance of serum and urinary interleukin- 6 in systemic lupus erythematosus patients. The Egyptian Rheumatologist 39:1-6

25. Demirag MD, Haznedaroglu S, Sancak B, Konca C, Gulbahar O, Ozturk MA et al (2009) Circulating hepcidin in the crossroads of anemia and inflammation associated with rheumatoid arthritis. Intern Med 48:421-426

26. Mok CC, Birmingham D, Ho LY, Hebert L, Rovin B (2013) THU0302 hepcidin, interleukin- 6 and anemia of chronic inflammation in systemic lupus erythematosus (SLE). Poster presentation. https://doi.org/10.1136/ annrheumdis-2013-eular.830

27. Isaacs JD, Harari O, Kobold U, Lee JS, Bernasconi C (2013) Effect of tocilizumab on haematological markers implicates interleukin-6 signalling in the anaemia of rheumatoid arthritis. Arthritis Res Ther 15:R204

28. Bregman DB, Morris D, Koch TA, He A, Goodnough LT (2013) Hepcidin levels predict nonresponsiveness to oral iron therapy in patients with iron deficiency anemia. Am J Hematol 88(2):97-101

29. Means RT Jr (2003) Recent developments in anemia of chronic disease. Curr Hematol Rep 2:116-121

30. Lee $\mathrm{P}$, Peng $\mathrm{H}$, Gelbart $\mathrm{T}$, Wang $\mathrm{L}$, Beutler $\mathrm{E}$ (2005) Regulation of hepcidin transcription by interleukin-1 and interleukin-6. Proc Natl Acad Sci U S A. 102:1906-1910

31. Malyszko J, Malyszko JS, Hryszko T, Pawlak K, Mysliwiec M (2005) Is hepcidin a link between anemia, inflammation and liver function in hemodialyzed patents? Am J Nephrol 25:586-590

32. Theurl I, Mattle V, Seifret M, Mariani M, Marth C, Weiss G (2006) Dysregulated monocyte iron homeostasis and erythropoietin formation in patients with anemia of chronic disease. Blood 107:4142-4148

33. Ganeb SS, Hamad GA, El-Tanawy RM, Hashaad NI, Ahmed IA, Gomah DK, Amer AS (2016) Correlations between serum prohepcidin level disease activity in rheumatoid arthritis and systemic lupus erythematous. Egypt Rheumatol Rehabil 43:102-107

\section{Publisher's Note}

Springer Nature remains neutral with regard to jurisdictional claims in published maps and institutional affiliations.

\section{Submit your manuscript to a SpringerOpen ${ }^{\circ}$ journal and benefit from:}

- Convenient online submission

- Rigorous peer review

- Open access: articles freely available online

High visibility within the field

- Retaining the copyright to your article

Submit your next manuscript at $\boldsymbol{\nabla}$ springeropen.com 